\title{
ANALYSIS OF QUALITY IMPROVEMENT AND EMPLOYEE EMPOWERMENT IN EFFORT OF PERFORMANCE IMPROVEMENT ON MANPOWER AND TRANSMIGRATION OFFICE OF KARAWANG REGENCY
}

\author{
Irma Hermayati \\ Universitas Singaperbangsa Karawang \\ Email : irma_hermayati@yahoo.com
}

\begin{abstract}
The purpose of this study is to analyze and assess the implementation of human resource empowerment, implementation of work programs, inhibiting factors in the empowerment of human resources, inhibiting factors in improving the quality of human resources and efforts to improve performance in the Department of Manpower and Transmigration Karawang regency.

This research is expected to contribute to the development of economics especially in the field of management science; As a contribution of scientific literature in the field of human resources management, as reference material in scientific writing, as an information material, both for leaders and employees at the Departemen of Manpower and Transmigration Karawang regency in the implementation of performance-based and career management as well as consideration and input for decision making.

The research was conducted by using qualitative method of single case study that is; Collect, present, analyze, triangulate and test the validity of data and make conclusions and suggestions. The focus of research in the field of training and job placement of the Department of Manpower and Transmigration Karawang regency. Unit of research respondents: Head of Department, Head of Division, Secretary of Service, Human Resource Consultant and Human Resources Expert.

Based on the results of the analysis, the following conclusions are obtained: the implementation of empowerment of human resources has not been implemented optimally, the implementation of work programs based on routine achievement, the factors that hamper the empowerment of human resources are the factors of human habit and discipline, the inhibiting factors Improving the quality of human resources is a factor of work culture that has formed from the first and efforts to improve performance by holding technical guidance of education and job training in the Department of Manpower and Transmigration Karawang regency.
\end{abstract}

Keywords: empowerment of human resources, performance.

\section{Latar Belakang Penelitian}

Struktur organisasi dan sistem manajemen pemerintahan saat ini sudah mengalami perubahan yang sangat pesat. Munculnya perubahan paradigma dalam sistem pengelolaan pemerintahan ini tentunya dapat menimbulkan permasalahanpermasalahan tersendiri, khususnya dalam implementasi di lapangan. Sebagai suatu organisasi di lingkungan pemerintahan, seperti halnya yang terdapat di Dinas Tenaga Kerja Dan Transmigrasi Bidang Bina Pelatihan Dan Penempatan 
Tenaga Kerja Kabupaten Karawang, tidak jarang muncul permasalahanpermasalahan yang berhubungan dengan adanya sentralisasi yang berlebihan, ketidakluwesan, komunikasi informasi yang tidak akurat serta tidak efisien, serta ketidaksiapan aparatur/pegawai pemerintahan dalam menghadapi perubahanperubahan tatanan di bidang ketenagakerjaan tersebut dan pemberian pelayanan kepada masyarakat, khususnya masyarakat pencari kerja.

Kondisi sekarang ini yang menjadi prasarat terlaksananya pemerintahan yang baik dibidang ketenagakerjaan, salah satunya adalah bahwa pemerintah daerah diharapkan mampu memainkan peranan dalam membuka peluang kerja dalam upaya memajukan daerah, dengan melakukan identifikasi potensi sumbersumber kerja dan mampu menetapkan penempatan kerja secara tepat, ekonomis, efisien dan efektif. Kondisional ini tentunya sangat membutuhkan adanya peningkatankualitas dan juga pemberdayaan aparatur pemerintahan / sumber daya manusia dengan potensi yang tinggi.

Kondisi yang muncul terkait dengan otonomi daerah adalah bagaimana kemampuan Pemerintah Daerah dilihat dari sumber daya manusia aparatnya mampu mewadahi aktivitas pemerintahan, pelayanan publik, dan pembangunan. Banyak daerah yang mengakui bahwa kemampuan sumber daya manusia aparaturnya masih perlu ditingkatkan (Dwiyanto, 2003:36). Pemerintah akhirakhir ini memberikan perhatian yang besar pada upaya-upaya peningkatan kemampuan aparaturdalam melaksanakan tugas-tugasnya, yakni memberikan pelayanan yang sebaik-baiknya kepada rakyat sesuai perannya sebagai abdi negara dan abdi masyarakat. Keberhasilan pembangunan nasional sangat ditentukan olehkeberhasilan aparatur negara dalam melaksanakan tugasnya. Terutama dari segi kepegawaian, karena itu aparatur pemerintah memiliki peranandan kedudukan yang penting sebagai motor penggerak dalamsemua aktivitas fungsi pemerintahan, selaras tuntutan reformasi yangmenghendaki pemerintahan yang bersih dari perbuatan amoral(Tjokroamidjoyo dalam Suharto,2002: 7 ).

Menurut hasil pengamatan awal penulis, terdapat fenomena yang terjadi pada kinerja pegawai Kantor Disnakertrans Kabupaten Karawang masih belum menunjukan kesuksesan dengan diharapkan, antara lain : pegawai yang terlambat masuk kantor, masih ada pegawai yang tidak memahami tugasnya, komunikasi vertical dan horizontal belum berjalan lancar, kurangnya pengawasan pimpinan terhadap kinerja pegawai, adanya hubungan yang kurang harmonis sesame pegawai, motivasi yang rendah ketika diberi pekerjaan tambahan, tingkat kehadiran pegawai Disnakertrans Kabupaten Karawang cukup tinggi akan tetapi, permasalahan yang sering terjadi adalah masih banyak pegawai yang melakukan pelanggaran disiplin dalam hal datang dan pulang kerja. Jam kerja untuk hari Senin-Jum'at adalah pukul 07.45 sampai dengan 15.45 , tetapi masih banyak yang hadir setelah jam tersebut dan pulang sebelum waktunya.

Berdasarkan informasi data empiris Lakip Disnakertrans Kabupaten Karawang tahun 2015, isu dan sasalah strategis Dinas Tenaga Kerja dan Transmigrasi Kabupaten Karawang adalah pemberdayaan sumber daya manusia dalam capaian program-program kerja sehingga sesuai dengan rencana strategis yang telah ditetapkan oleh Dinas (Sumber : Lakip Disnaker, 2015). 
Melihat begitu banyak urusan dan program kerja yang harus dilaksanakan oleh aparatur pemerintahan di Dinas Tenaga Kerja Dan Transmigrasi Bidang Bina Pelatihan Dan Penempatan Tenaga Kerja Kabupaten Karawang saat ini dengan keterbatasan dukungan sumber daya manusia yang ada, tentunya sangat membutuhkan adanya inovasi dan skala prioritas yang ketat sehingga pelaksanaan dari semua urusan tersebut dapat dilaksanakan. Inovasi yang dapat dilakukan terkait dengan keterbatasan sumber daya manusia yang ada di lingkungan Dinas Tenaga Kerja Dan Transmigrasi Bidang Bina Pelatihan Dan Penempatan Tenaga Kerja Kabupaten Karawang ini, diantaranya dengan melakukan peningkatan kualitas sumber dan pemberdayaan aparatur pemerintahan yang ada. Memperhatikan kondisional tersebut, maka peneliti tertarik untuk mengangkat permasalahan kedalam suatu penelitian dengan judul : "Analisis Peningkatan Kualitas Dan Pemberdayaan Pegawai Dalam Upaya Peningkatan KinerjaPada Dinas Tenaga Kerja Dan Transmigrasi Kabupaten Karawang”

\section{Tujuan Penelitian:}

Tujuan yang ingin dicapai dari penelitian ini adalahuntuk menganalisis dan mengkaji :

1. Implementasi pemberdayaan sumber daya manusia yang dilaksanakan di Dinas Tenaga Kerja Dan Transmigrasi Bidang Bina Pelatihan Dan Penempatan Tenaga Kerja Kabupaten Karawang?

2. Pelaksanaan program kerja di Dinas Tenaga Kerja Dan Transmigrasi Bidang Bina Pelatihan Dan Penempatan Tenaga Kerja Kabupaten Karawang?

3. Faktor apa saja yang menjadi penghambat dalam pemberdayaan sumber daya manusia yang dilaksanakan di Dinas Tenaga Kerja Dan Transmigrasi Bidang Bina Pelatihan Dan Penempatan Tenaga Kerja Kabupaten Karawang?

4. Faktor apa yang menjadi penghambat dalam peningkatan kualitas sumber daya manusia di Dinas Tenaga Kerja Dan Transmigrasi Bidang Bina Pelatihan Dan Penempatan Tenaga Kerja Kabupaten Karawang ?

5. Upaya peningkatan kinerja kerja di Dinas Tenaga Kerja Dan Transmigrasi Bidang Bina Pelatihan Dan Penempatan Tenaga Kerja Kabupaten Karawang?

\section{Tinjauan Pustaka}

\section{Pengertian Peningkatan Kualitas SDM}

Kata kualitas memiliki banyak definisi yang berbeda, dan bervariasi dari yang konvensional sampai yang lebih strategik. Definisi konvensionaldari kualitas biasanya menggambarkan karakteristik langsung dari suatu produk seperti: performansi (performance), keandalan (reliability), mudah dalam penggunaan (easy of use), dan estetika (esthetics). Kualitas adalah segala sesuatu yang mampu memenuhi keinginan atau kebutuhan pelanggan (meeting the needs of costumer). Di samping pengertian kualitas telah disebutkan di atas, kualitas juga dapat diartikan sebagai segala sesuatu yang menentukan kepuasan pelanggan dan upaya perubahan ke arah perbaikan terus menerus sehingga dikenal istilah: Q-Match (Quality= Meets Agreed Terms and Changes).

Berdasarkan definisi tentang kualitas baik yang konvensional maupun yang lebih strategik, bahwa pada dasarnya kualitas mengacu kepada pengertian pokok berikut: 
1. Kualitas terdiri dari sejumlah keistimewaan produk/jasa, baik keistimewaan langsung maupun keistimewaan atraktif yang memenuhi keinginan pelanggan (masyarakat) dan dengan demikian memberikan kepuasan atas penggunaan produk itu.

2. Kualitas terdiri dari segala sesuatu yang bebas dari kekurangan atau kerusakan.

Dalam hal pengelolaan program-program pemerintah termasuk dalam hal pelayanan yang dapat diberikan oleh aparatur/pegawai (khususnya di Dinas Tenaga Kerja Dan Transmigrasi Bidang Bina Pelatihan Dan Penempatan Tenaga Kerja Kabupaten Karawang) maka produk yang dimaksudkan dalam pemahaman kualitas tersebut adalah berupa jasa pelayanan yang dapat diberikan kepada masyarakat dalam hal penempatan tenaga kerja.

Kualitas sumber daya manusia ini menyangkut dua aspek yakni aspek fisik dan non fisik yang menyangkut kemampuan bekerja dan ketrampilan-ketrampilan lain. Oleh sebab itu upaya meningkatkan kualitas sumber daya manusia ini juga dapat diarahkan kepada kedua aspek tersebut. Untuk meningkatkan kualitas fisik dapat diupayakan melalui program-program kesehatan dan gizi. Sedangkan untuk kualitas/ kemampuan nonfisik, maka upaya pendidikan dan pelatihan termasuk peningkatan moral adalah yang paling diperlukan. Upaya inilah dimaksudkan dengan penembangan sumber daya manusia. Mengingat faktor pendidikan sangat dibutuhkan dalam upaya peningkatan kualitas Sumber Daya Manusia, maka setiap institusi harus menempatkan pendidikan sebagai prioritas utama.

\section{Pengertian Pemberdayaan SDM}

Sedarmayanti (2000:123) mengemukakan bahwa : "Pemberdayaan Sumber Daya Manusia merupakan salah satu upaya yang wajib dilakukan bagi terciptanya sumber daya manusia yang berkualitas, memiliki kemampuan memanfaatkan, mengembangkan dan menguasai ilmu pengetahuan dan tekhnologi serta kemampuan menajemen". Dari definisi diatas dapat diambil beberapa hal penting dari pengertian pemberdayaan, yaitu : Dapat meningkatkan mutu sumber daya manusia yang berkualitas dan produktif serta dapat mengisi lapangan kerja dan mampu pula menciptakan dan memperluas kesempatan kerja.

Ada beberapa perbedaan definisi Pemberdayaan Sumber Daya Manusia yang dikemukakan oleh para ahli. Menurut Fandi Tjipto (2000:128) menyatakan bahwa :"Empowerment atau pemberdayaan dapat diartikan sebagai perlibatan pegawai yang benar-benar berarti (signifikan)".Menurut Atmosoeprapto (2002:64), menjelaskan tentang pemberdayaan sumber daya manusia sebagai berikut :"Pemberdayaan sumber daya manusia melalui kegiatan pembelajaran harus bermuara pada terwujudnya manusia yang mampu mengaktualisasikan dirinya". Seorang pemimpin (manager) apapun tingkatannya, sesungguhnya mempunyai kemampuan "pemberdayaan" itu, tetapi boleh jadi tidak pernah menggunakannya, mungkin karena tidak pernah menyadari bahwa sebenarnya bisamelakukan hal tersebut.

Dari beberapa definisi di atas, penulisakan memberikan batasan mengenai pengertian Pemberdayaan Sumber Daya Manusia yaitu sebagai berikut :

1. Pemberdayaan sesungguhnya meningkatkan keberhasilan manajer dengan cara memberikan kekuasaan kepada orang lain. 
2. Pemberdayaan tidak akan mendatangkan mukjizat, namun akan menunjukan suatu cara agar dapat mencapai hasil-hasil yang lebih baik dari pada yang selama ini dilakukan asalkan kita bersedia mencoba dan terus menyempurnakannya.

Berdasarkan beberapa pengertian yang tertera di atas maka penulis dapat menyimpulkan bahwa empowerment (pemberdayaan) adalah suatu proses pengembangan diri sumber daya pegawai dalam melakukan sesuatu dengan cara memberikan tanggung jawab dan kewenangan diharapkan mereka dapat memaksimalkan kemampuan dan keahlian diri mereka sendiri dalam mengerjakan tanggung jawabnya.

Pemberdayaan merupakan suatu hal yang sangat penting oleh karena itu untuk mencapai hasil pemberdayaan yang sesuai dengan yang diharapkan. Aileen Mitchell Stewart (2006:112-128), mengemukakan bahwa terdapat delapan perinsip pemberdayaan (The eight es of empowerment), yang kemudian dikenal dengan prinsip "E", kedelapan butir prinsip tersebut satu sama lain saling mempengaruhi, sehingga semua prinsip akan bisa berjalan selaras secara bersamaan. Adapun yang dimaksud 8 prinsip pemberdayaan tersebut adalah :

1. Mengembangkan prinsip bersama

2. Mendidik

3. Menjauhkan rintangan-rintangan

4. Mengungkapkan

5. Menyemangati

6. Memperlengkapi

7. Menilai

8. Mengharapkan

Sedangkan menurut Dvrye, (2002:82) mengemukakan bahwa terdapat tujuh langkah-langkah seven keys of empowermentyaitu :

1. Mengurangi hambatan-hambatan birokrasi yang tidak perlu untuk membuat pegawai lebih bertanggung jawab dan memiliki daya tanggap, maksudnya agar pegawai dapat bekerja lebih baik lagi dan pengambilan keputusan bisa berjalan dengan cepat.

2. Membiasakan pegawai untuk menanggapi permasalahan pelanggan dengan berkata "ya" dari pada menolaknya, maksudnya jika ada pelanggan yang mengeluh dan meminta ada perbaikan lebih baik menjawab ya akan kita perbaiki daripada menolaknya dengan berkata tidak pelanggan (masyarakat) akan merasa tersinggung.

3. Memberikan keberanian kepada pegawai untuk mengambil resiko dan belajar dari kesalahan, maksudnya agar pegawai mengetahui letak-letak kesalahan dalam bekerja agar tidak salah menjalankan pekerjaannya di kemudian hari.

4. Memberikan dukungan kepada pegawai untuk bekerja dengan benar, maksudnya agar pegawai merasa dibutuhkan dalam pekerjaan, dan agar pegawai bias lebih baik lagi dalam menyelesaikan pekerjaannya.

5. Memperkenalkan tekhnik bekerja dan memberikan penghargaan terhadap pegawai yang bekerja dengan baik, maksudnya agar pegawai lebih termotivasi lagi dalam bekerja sehingga hasil pekerjaannya dapat di selesaikan tepat waktu dan hasil pekerjaannya memuaskan. 
6. Menciptakan kondisi atau perasaan dibutuhkan diantara pegawai, baik dalam pelayanan intern maupun pelayanan kepada masyarakat luar, maksudnya agar pegawai merasa diakui di dalam lingkungannya atau tempat dia bekerja sehinga dapat menimbulkan motivasi dalam bekerja hingga mencapai produktivitas yang tinggi.

7. Dalam organisasi sendiri, akan ditempuh sebuah bentuk peningkatan palayanan dari pegawai kepada perusahaan.

\section{Pengertian Kinerja}

Kinerja menurut Faustino Cardoso Gomes dalam Mangkunegara (2009:9) mengemukakan bahwa kinerja sebagai ungkapan seperti output, efisiensi serta efektivitas sering dihubungkan dengan produktivitas. Mangkunegara (2009:9) menyatakan bahwa kinerja (prestasi kerja) adalah hasil kerja secara kualitas dan kuantitas yang dicapai oleh seorang dalam melaksanakan tugasnya sesuai dengan tanggung jawab yang diberikan kepadanya.

Kinerja adalah tentang melakukan pekerjaan dan hasil yang dicapai dari pekerjaan tersebut. Kinerja adalah hasil pekerjaan yang mempunyai hubungan yang kuat dengan tujuan organisasi, kepuasan konsumen dan memberikan kontribusi ekonomi (Amstrong dan Baron dalam Wibowo, 2010:2). Dengan demikian kinerja adalah sesuatu hasil yang dicapai, prestasi yang diperlihatkan, kemampuan kerja pegawai dalam melaksanakan tugas sesuai dengan standar atau persyaratan pekerjaan yang telah ditetapkan sebelumnya.

Berdasarkan pengertian kinerja diatas, maka dapat ditarik kesimpulan sebagai berikut :

1. Penilaian kinerja meruakan evaluasi terhadap perilaku, kinerja dan potensi pengembangan yang telah dilakukan.

2. Penilaian kinerja ini pada dasarnya merupakan suatu proses dalam menentukan suatu keberhasilan pelaksanaan tugas para pegawai.

3. Penilaian kinerja mengembangkan realitas yang nyata dengan standar yang ingin kita capai.

4. Penilaian kinerja dilaksanakan oleh atasan terhadap bawahan.

5. Penilaian kinerja ini akan menentukan kebijaksanaan selanjutnya

6. Penilaian kinerja pegawai bertujuan untuk pengembangan organisasi dan harus bermanfaat bagi pegawai

Berdasarkan uraian diatas, dapat memberikan bahwa dengan adanya penilaian terhadap kinerja pegawai, hendaknya dapat menimbulkan perasaan puas dalam diri pegawai. Para pegawai merasa dengan cara ini hasil kerja mereka dinilai oleh pimpinan dengan sewajarnya dan sekaligus mengetahui kelemahankelemahan yang terdapat dalam diri pegawai.

\section{Proposisi}

Proposisi penelitian ini adalah :

1. Pemberdayaan sumber daya manusia di Dinas Tenaga Kerja Dan Transmigrasi Bidang Bina Pelatihan Dan Penempatan Tenaga Kerja Kabupaten Karawang dapat dilakukan secara optimal. 
2. Pelaksanaan program kerja yang ada di Dinas Tenaga Kerja Dan Transmigrasi Bidang Bina Pelatihan Dan Penempatan Tenaga Kerja Kabupaten Karawang dapat dilakukan secara optimal.

3. Faktor penghambat pemberdayaan sumber daya manusia di Dinas Tenaga Kerja Dan Transmigrasi Bidang Bina Pelatihan Dan Penempatan Tenaga Kerja Kabupaten Karawang dapat diatasi dengan baik.

4. Faktor penghambat peningkatan kualitas sumber daya manusia diDinas Tenaga Kerja Dan Transmigrasi Bidang Bina Pelatihan Dan Penempatan Tenaga Kerja Kabupaten Karawang dapat diatasi dengan baik.

5. Upaya peningkatkan kinerja pada Dinas Tenaga Kerja Dan Transmigrasi Bidang Bina Pelatihan Dan Penempatan Tenaga Kerja Kabupaten Karawang dapat terlaksana dengan baik

\section{Objek dan Metode Penelitian \\ Latar Penelitian}

Metodologi penelitian merupakan pendekatan terhadap penetapan tata cara atau prosedur penelitian, yang dilakukan secara tersusun dan sistematik untuk mencapai tujuan penelitian yang dirumuskan.

Dalam penelitian ini, penulis menggunakan metode kualitatif dikarenakan dalam pembahasan mengenai pelaksanaan program kerjadi lingkungan Dinas Tenaga Kerja Dan Transmigrasi Bidang Bina Pelatihan Dan Penempatan Tenaga Kerja Kabupaten Karawang, dapat dilakukan dengan atribut dan variable. Yang penulis kaji yaitu secara atributpemberdayaan sumber daya manusia dalam upaya peningkatan kualitas program kerja di Dinas Tenaga Kerja Dan Transmigrasi Bidang Bina Pelatihan Dan Penempatan Tenaga Kerja Kabupaten Karawang, sehingga dalam penelitian ini penulis tidak mencari pengaruh keterkaitan variable sebagaimana ada batasan-batasan masalah, melaikan menganalisis berdasarkan situasi sosial yang terjadi di Dinas Tenaga Kerja Dan Transmigrasi Bidang Bina Pelatihan Dan Penempatan Tenaga Kerja Kabupaten Karawang.

\section{Metode dan Prosedur Penelitian}

Penelitian kualitatif menurut Moleong (2007:6) adalah penelitian yang bermaksud untuk memahami fenomena tentang apa yang dialami oleh subjek penelitian misalnya perilaku, persepsi, motivasi, tindakan, dan lain-lain, secara holistik, dan dengan cara deskripsi dalam bentuk kata-kata dan bahasa, pada suatu konteks khusus yang alamiah dan dengan memanfaatkan berbagai metode alamiah.

Bogdan dan Taylor dalam Moleong (2007:4) mengemukakan bahwa metodologi kualitatif sebagai prosedur penelitian yang menghasilkan data deskriptif berupa kata-kata tertulis atau lisan dari orang-orang dan perilaku yang dapat diamati. David Williams dalam Moleong (2007:5) mengemukakan bahwa penelitian kualitatif adalah pengumpulan data pada suatu latar alamiah, dengan menggunakan metode alamiah, dan dilakukan oleh orang atau peneliti yang tertarik secara alamiah.

Penelitian kualitatif bertujuan memperoleh gambaran seutuhnya mengenai suatu hal menurut pandangan manusia yang diteliti. Penelitian kualitatif 
berhubungan dengan ide, persepsi, pendapat atau kepercayaan orang yang diteliti dan kesemuanya tidak dapat diukur dengan angka.

Dalam penelitian kualitatif ini, gejala bersifat holistik atau menyeluruh dan tidak dapat dipisah-pisahkan sehingga tidak atau menetapkan penelitiannya berdasarkan variabel penelitian, sehingga peneliti kualitatif tidak akan menetapkan penelitian hanya berdasarkan variabel penelitian, tetapi keseluruhan situasi sosialyang diteliti yang meliputi aspek tempat (place), pelaku (actor), dan aktivitas (activity) yang berinteraksi secara sinergis.

\section{Data dan Sumber Data Jenis Data}

Data adalah fakta-fakta sebagai bukti empirik. Bogdan dan Taylor (Moleong, 2007:3) mengemukakan bahwa metodologi kualitatif merupakan prosedur penelitian yang menghasilkan data deskriptif berupa kata-kata tertulis maupun lisan. Penelitian kualitatif menghasilkan tiga jenis data, berupa catatan lapangan, audio rekaman (dan kadang-kadang video), dan transkrip,(Emily Name, 2005:12). Penelitian ini akan menghasilkan data kualitatif berupa konsep-konsep pemberdayaan sumber daya manusia di lingkungan Dinas Tenaga Kerja Dan Transmigrasi Bidang Bina Pelatihan Dan Penempatan Tenaga Kerja Kabupaten Karawang.

Data diambil dari hasil wawancara dengan Kepala Dinas, beberapa Kepala Bidang (Kabid), Kepala Seksi (Kasi), Kepala Sub-Bagian (Kasubag), Pelaksana di berbagai bidang dan pihak-pihak yang terkait dengan Dinas Tenaga Kerja Dan Transmigrasi Bidang Bina Pelatihan Dan Penempatan Tenaga Kerja Kabupaten Karawang. Selain itu juga data diambil melalui observasi langsung di lapangan dan studi dokumentasi.

Dalam penelitian ini tidak menutup kemungkinan adanya data kuantitatif sebagai pendukung dari deskripsi kontekstual, seperti berkaitan dengan profil Dinas Tenaga Kerja Dan Transmigrasi Bidang Bina Pelatihan Dan Penempatan Tenaga Kerja Kabupaten Karawang, sumber daya manusia serta data yang berasal dari berbagai potensi terkait dengan promosi jabatan di lingkungan tersebut.

\section{Sumber Data}

Berdasarkan sumbernya, data yang diambil dalam penelitian diklasifikasikan ke dalam data primer dan data sekunder. Data primer adalah data yang diambil langsung dari sumbernya oleh peneliti, yang dikumpulkan melalui penggunaan survei, pertemuan, fokus grup diskusi, aksesi, wawancara atau metode lain yang melibatkan kontak langsung dengan responden, khususnya para pegawai yang ada di Dinas Tenaga Kerja Dan Transmigrasi Bidang Bina Pelatihan Dan Penempatan Tenaga Kerja Kabupaten Karawang. Data sekunder adalah data yang ada yang telah, atau akan dikumpulkan orang lain untuk tujuan lain.

Yang akan menjadi data primer dalam penelitian ini adalah data untuk pertamakalinya diambil oleh peneliti berupa hasil wawancara, hasil observasi, hasil diskusi, mengenai aspek manajerial dan pelayanan pegawai terkait promosi jabatan yang telah dilakukan oleh Dinas Tenaga Kerja Dan Transmigrasi Bidang Bina Pelatihan Dan Penempatan Tenaga Kerja Kabupaten Karawang, serta data- 
data yang mendukung terkait dengan promosi jabatan baik yang berasal dari pihak internal maupun dari pihak eksternalDinas Tenaga Kerja Dan Transmigrasi Bidang Bina Pelatihan Dan Penempatan Tenaga Kerja Kabupaten Karawang.

Data sekunder dalam penelitian ini adalah data yang berasal dari studi dokumetasi meliputi aspek profil keorgansiasian Dinas Tenaga Kerja Dan Transmigrasi Bidang Bina Pelatihan Dan Penempatan Tenaga Kerja Kabupaten Karawang, profil sumber daya manusia, perundang-undang tentang kepegawaian di lingkungan Pegawai Negeri Sipil serta data-data pendukung lain yang sudah ada yang berhubungan dengan analisis promosi jabatan yang berasal dari internal maupun dari pihak eksternal Dinas Tenaga Kerja Dan Transmigrasi Bidang Bina Pelatihan Dan Penempatan Tenaga Kerja Kabupaten Karawang.

\section{Teknik Pengumpulan Data}

Menurut Suryana (2010: 23) dan Sugiyono (2010:63) teknik pengumpulan data kualitatif digunakan melalui wawancara secara mendalam (in dept interview), observasi, serta, dokumentasi dan triangulasi.

Teknik wawancara secara mendalam akan dilakukan dengan Kepala Bidang, Pemangku Jabatan Fungsional, seluruh Kepala Seksi, dan seluruh pegawaiyang ada serta pihak-pihak yang terkait dengan Dinas Tenaga Kerja Dan Transmigrasi Bidang Bina Pelatihan Dan Penempatan Tenaga Kerja Kabupaten Karawang. Bahan wawancara dipersiapakan sesuai dengan masalah yang akan diteliti. Observasi dilakukan untuk melihat langsung pelaksanaan promosi jabatan terkait dengan aspek manajerial dan pelayanan pegawai serta dalam kegiatannya agar lebih memahami kejadian nyata serta mendokumentasikan segala kejadian yang berkaitan dengan penelitian. Wawancara dengan para pihak, pemeriksaan data serta mengembangkan kajian yang diteliti, sehingga didapatkan data terbaru, juga digunakan untuk mengetahui keabsahan data (triangulasi), sehingga terdapat kesesuaian dengan proposisi tentang pencapaian program kerja, ketersediaan sumber daya manusia (SDM), perwujudan pemberdayaan (SDM) serta peningkatkan kualitas SDM di Dinas Tenaga Kerja Dan Transmigrasi Bidang Bina Pelatihan Dan Penempatan Tenaga Kerja Kabupaten Karawang.Pemberdayaan dan peningkatan kualitas sumber daya yang ada di Dinas Tenaga Kerja Dan Transmigrasi Bidang Bina Pelatihan Dan Penempatan Tenaga Kerja Kabupaten Karawangharus sinergikan, sehingga dapat mensukseskan program kerja yang ada.

\section{Instrumen Penelitian}

Pendekatan yang akan digunakan dalam penelitian ini adalah pendekatan kualitatif. Sedangkan metodenya menggunakan studi fenomenologi.Fenomenologi menurut Creswell, merupakan strategi penelitian dimana peneliti mengidentifikasi hakikat pengalaman manusia tentang fenomena tertentu. Memahami pengalaman-pengalaman hidup, menjadikan filsafat fenomenologi sebagai suatu metode penelitian yang prosedurnya mengharuskan peneliti untuk mengkaji sejumlah subjek, dengan terlibat secara langsung dan relatif lama di dalamnya untuk mengembangkan pola-pola dan relasi-relasi makna (Moustakas, 1994:12).Dalam proses ini, peneliti mengesampingkan terlebih 
dahulu pengalaman-pengalaman pribadinya agar dapat memahami pengalaman-pengalaman partisipan yang diteliti.(Nieswiadomy, 1993:23).

Karakteristik penelitian kualitatif menurut Bogdan and Biklen dalam Sugiyono (2012:13-14) adalah sebagai berikut:

a. Penelitian kualitatif memiliki setting alamiah sebagai sumber data langsung dan peneliti merupakan instrumen kunci.

b. Penelitian kualitatif deskriptif. Data yang dikumpulkan adalah dalam bentuk kata-kata, gambar, dan bukan angka.

c. Penelitian kualitatif berkaitan dengan proses dan bukan sekedar hasil atau produk.

d. Penelitian kualitatif untuk menganalisis suatu data secara induktif.

e. "Arti" adalah penting untuk pendekatan kualitatif.

Berdasarkan karakteristik tersebut dikemukakan bahwa penelitian kualitatif itu:

a. Dilakukan pada kondisi alamiah (sebagai lawannya adalah eksperimen)langsung ke sumber data dan peneliti adalah instrumen kunci.

b. Penelitian kualitatif lebih bersifat deskriptif. Data yang terkumpul berbentuk kata-kata atau gambar, sehingga tidak menekankan pada angka.

c. Penelitian kualitatif lebih menekankan pada proses dari pada produk atau outcome.

d. Penelitian kualitatif melakukan analisis data secara induktif.

e. Penelitian kualitatif lebih menekankan pada makna (data di balik yangteramati).

Ada beberapa pertimbangan yang menjadi landasan, mengapa peneliti kemudian memilih pendekatan yang sifatnya kualitatif dalam penelitian ini, antara lain:

Pertama, kajian pemberdayaan sumber daya manusia dikaitkan dengan tujuan meningkatkan kualitas program kerja merupakan fenomena yang masih kompleks, sehingga membutuhkan kajian lebih komprehensif dan mendalam. Melalui pendekatan yang sifatnya kualitatif diharapkan akan mampu mengungkap dan memberikan informasi yang akurat sehingga sangat membantu proses interpretasi data dan informasi yang diperoleh.

Kedua, melalui proses ini juga diharapkan muncul proposisi baru melalui interpretasi interaksi antara parameter yang diteliti, yang selanjutnya digunakan untuk membangun kategori dan memberikan penjelesan terhadap fenomena yang diteliti. Dengan demikian, aktivitas penelitian ini dicirikan oleh kegiatan mengumpulkan, menggambarkan, dan menafsirkan data tentang situasi yang dialami, hubungan tertentu, kegiatan, pandangan, pertentangan, kerjasama, sikap yang ditunjukkan atau kecenderungan yang tampak dalam proses yang sedang berlangsung.

Ketiga, melalui kajian ini diharapkan dapat diperoleh makna, gambaran fenomena, fakta, dan hubungan fenomena pemberdayaan sumber daya manusia dalam kaitannya dengan upaya meningkatkan program kerja.

\section{Keabsahan Data}

Penelitian kualitatif harus mengungkap kebenaran yang objektif, oleh karena itu keabsahan data dalam sebuah penelitian kualitatif sangat penting. Setiap penelitian harus memiliki kredibilitas sehingga dapat 
dipertanggungjawabkan. Guna memenuhi keabsahan data penelitian ini, dilakukan triangulasi dengan sumber data dan melakukan memberchek. Untuk memeriksa keabsahan data, dilakukan pengujian kredibilitas, dependabilitas, transferabilitas, dan konfirmabilitas. (Sugiyono, 2009:270-276)

\section{Hasil Penelitian}

Hasil penelitian ini meliputi beberapa aspek di Disnakertrans Kabupaten Karawang dimana kegiatan organisasi sedang berjalan, atau di tempat dimana nara sumber bersedia diwawancarai. Pelaku dan nara sumber yang diamati atau diwawancarai adalah : Kepala Dinas, Sekretaris Dinas, Kepala Bidang, Kepala Seksi, Konsultan SDM, Ahli (expert judgement) di bidang SDM. Pengamatan dan wawancara yang dilakukan mengenai: pemberdayaan karyawan yang dilakukan oleh organisasi dan konsep atau pendekatan apa yang digunakan, dan kaitannya dalam upaya mengoptimalkan potensi pemberdayaan dan kualitas sumber daya manusia dan Peningkatan Kinerja Pegawai.

Implementasi pemberdayaan sumber daya manusia yang dilaksanakan di Dinas Tenaga Kerja Dan Transmigrasi Bidang Bina Pelatihan Dan Penempatan Tenaga Kerja Kabupaten Karawang, secara faktual bahwa dengan dapat dilaksanakan program kerja pada Bidang Binapenta Disnakertrans Kabupaten Karawang, dengan cara memberdayakan Sumber Daya Manusia yang ada di Bidang Binapenta Disnakertrans sesuai dengan tupoksinya,meskipun belum optimal.

Pelaksanaan program kerja di Dinas Tenaga Kerja Dan Transmigrasi Bidang Bina Pelatihan Dan Penempatan Tenaga Kerja Kabupaten Karawang, dapat di katakan pelaksanaan program berjalan dan dapat dilaksanakan dengan baik, namun pelaksanaan program kurang maximal dikarenakan terbatasnya SDM yang ada sehingga di perlukan peningkatan kemampuan melalui Diklat khusu dan pelatihan dalam rangka meningkatkan pelaksanaan program kerja.

Faktor apa saja yang menjadi penghambat dalam pemberdayaan sumber daya manusia yang dilaksanakan di Dinas Tenaga Kerja Dan Transmigrasi Bidang Bina Pelatihan Dan Penempatan Tenaga Kerja Kabupaten Karawang, kondisi saat ini khususnya pada Bidang Binapenta Disnakertrans Kabupaten Karawang dilihat dari SDM yang ada di masing-masing jelas dapat dikatakan kurang tenaga ahli baik diklat secara fungsional atau di dasari latar belakang pendidikan dan di lihat dari skill masing-masing personil, ini terjadi dikarenakan tidak ada kaderisasi pegawai, yang maximal sehingga SDM yang ada hanya itu-itu saja dan terbatasnya SDM, factor penghambat pemberdayaan SDM pada Bidang Binapenta Disnakertrans Kabupaten Karawang, diantaranya adalah factor kebiasan manusia dan disiplin.

Faktor apa yang menjadi penghambat dalam peningkatan kualitas sumber daya manusia di Dinas Tenaga Kerja Dan Transmigrasi Bidang Bina Pelatihan Dan Penempatan Tenaga Kerja Kabupaten Karawang, terbatasnya jumlah personil baik yang sudah mendapatkan pelatihan maupun belum karena kondisi kepegawaiannya yang diantaranya masih status THL atau belum menjadi PNS, sedangkan jumlah personil yang sudah PNS dan sudah di diklatkan jumlahnya terbatas, dan factor penghambat peningkatan kualitas SDM adalah Budaya Kerja yang sudah terbentuk dari dulu. 
Upaya peningkatan kinerja kerja di Dinas Tenaga Kerja Dan Transmigrasi Bidang Bina Pelatihan Dan Penempatan Tenaga Kerja Kabupaten Karawang, dengan mengirimkan personil yang ada untuk diikutsertakan dalam pelatihanpelatihan sesuai dengan kebutuhan dalam rangka peningkatan kinerja sesuai dengan tugas fungsi pegawai, selain itu pembinaan dan pendekatan kepada pegawai dalm rangka mendisiplinkan pegawai agar dapat mendorong meningkatkan kemampuan sehingga sedikit demi sedikit setiap pegawai sadar kepada tugas pokok dan fungsi, dengan demikian capaian kinerja diharapkan dapat meningkat.

\section{Pembahasan Hasil Penelitian}

Hasil penelitian ini meliputi beberapa aspek di Disnakertrans Kabupaten Karawang dimana kegiatan organisasi sedang berjalan, atau di tempat dimana nara sumber bersedia diwawancarai. Pelaku dan nara sumber yang diamati atau diwawancarai adalah : Kepala Dinas, Sekretaris Dinas, Kepala Bidang, Kepala Seksi, Konsultan SDM, Ahli (expert judgement) di bidang SDM. Pengamatan dan wawancara yang dilakukan mengenai: pemberdayaan karyawan yang dilakukan oleh organisasi dan konsep atau pendekatan apa yang digunakan, dan kaitannya dalam upaya mengoptimalkan potensi pemberdayaan dan kualitas sumber daya manusia dan kualitas.

Pemberdayaan (Empowerment) merupakan alat penting dan strategis untuk memperbaiki, memperbaharui dan meningkatkan kinerja organisasi baik organisasi yang bergerak dalam kegiatan pemerintahan maupun organisasi yang bergerak dalam kegiatan dunia usaha/swasta. Mengapa penting dan strategis karena pemberdayaan dalam suatu organisasi adalah memberikan "daya yang lebih" daripada daya sebelumnya terhadap berbagai hal seperti: unsur-unsur dalam organisasi/manajemen, aspek-aspek/komponen-komponen organisasi/manajemen, kompetensi, wewenang dan tanggungjawab dalam organisasi/manajemen tersebut. Pemberdayaan dimaksudkan dalam hal ini adalah memberikan "daya" (energi atau power) yang lebih daripada sebelumnya, artinya dapat ditunjukkan dalam hal:tenaga, daya, kemampuan, kekuatan, keberadaan, peranan, wewenang dan tanggungjawab.

Pemberdayaan Sumber Daya Manusia (Empowering of Human Resources atau Empowerment of Human Resources) merupakan suatu aspek manajemen yang sangat kunci dan strategis, karena Sumber Daya Manusia menunjukkan daya yang bersumber dari manusia yang akan memberi daya terhadap sumber-sumber lainnya dalam suatu manajemen, untuk mencapai tujuan sebagaimana ditetapkan. Apabila manusia tidak dapat menunjukkan daya dan memberikan daya terhadap sumber-sumber lainnya, maka dapat dipastikan manajemen dalam organisasi tersebut akan tidak ekonomis, tidak efisien, dan tidak efektif.

Hubungan antara pemberdayaan dan perubahan Perubahan (change) adalah kata-kunci yang menjadi induk untuk bermacam-macam kegiatan misalnya peningkatan, perbaikan, reformasi, efisiensi, penyempurnaan, transportasi, evolusi, revolusi, kehancuran, perusakan, termasuk pemberdayaan; b. Perubahan yang direncanakan dan perubahan yang alami;

Pada umumnya perubahan ada yang direncanakan dan ada yang secara alami (dibiarkan). Sering perubahannya tidak seperti yang diharapkan (unexpected 
change) berbeda dengan perubahan yang memang dikehendaki (planned change). Disamping itu perubahan yang dibiarkan (alami) akan mengalami proses yang lebih lama sedangkan yang direncanakan akan mengalami proses waktu yang lebih disesuaikan dengan tujuannya. Dalam keadaan yang linear orang menghendaki perubahan yang terencana, sedangkan dalam kejadian-kejadian yang tidak bisa diperhitungkan, unexpected result, unpredictable orang sering terpaksa menerima perubahan yang tidak direncanakan, perubahan yang mendadak, bahkan perubahan yang sebelumnya tidak terduga atau bahkan tidak terpikirkan. Pada umumnya orang senang menerima perubahan yang bisa diperhitungkan dan direncanakan sebelumnya. Pemberdayaan sudah tidak lagi mengandalkan kepada organisasi struktural yang bersifat hirarkis, melainkan sudah berubah andalannya kepada kelompok yaitu antar individual dengan lingkup yang lebih kecil.

Pelaksanaan program kerja yang dilaksanakan di Dinas Tenaga Kerja Dan Transmigrasi Bidang Bina Pelatihan Dan Penempatan Tenaga Kerja Kabupaten Karawang berjalan sesuai rutinitas program yang direncanakan. Dalam kaitan pemberdayaan SDM dalam suatu organisasi, beberapa hal yang perlu diperhatikan dan atau dipersiapkan dan bahkan dapat dijadikan sebagaimana pelaksanaan dari program kerja sebagai berikut:

1. Adanya dorongan untuk berani mencoba mengambil bagian dalam proses pembaharuan yang dilakukan dalam organisasinya (encouragement);

2. Diberikannya tantangan. bagi para pelaksana pembaharuan untuk dapat bergerak dan termotivasi dalam proses pembahuruan (chalenger);

3. Diberikannya peluang untuk terlibat dan mengambil peran dalam proses pembaharuan (opportunity);

4. Pemberian kesempatan untuk mengikuti pelatihan dan diberikan bimbingan dalam mencoba melaksanakan suatu inovasi (training and guidance);

5. Pemberian dukungan baik moril maupun pendukung lainnya, sehingga pihak yang bersangkutan dapat ikut dalam proses pembahuruan (support)

6. Disediakannya penghargaan yang tepat untuk setiap keberhasilan dalam melaksanakan atau mencoba suatu pembahuruan (reward).

Faktor yang menjadi penghambat dalam pemberdayaan sumber daya manusia yang dilaksanakan di Dinas Tenaga Kerja Dan Transmigrasi Bidang Bina Pelatihan Dan Penempatan Tenaga Kerja Kabupaten Karawang adalah peran kepemimpinan dalam mengatur sumber daya kebersamaan dalam orgranisasi.

Membangun budaya kebersamaan dalam kehidupan organisasi adalah suatu alat untuk pemberdayaan. Hal ini dapat dipahami, karena esensi pemberdayaan adalah sebagai proses transformasi ataupun instruksi dari berbagai pihak yang bernuasa saling menumbuhkan, saling meningkatkan, saling memperkuat dan saling menambah daya bagi masing-masing SDM yang berintraksi sehingga menghasilkan energi yang kuat dan kondusif dalam rangka mencapai tujuan organisasi.

Faktor yang menjadi penghambat dalam peningkatan kualitas sumber daya manusia di Dinas Tenaga Kerja Dan Transmigrasi Bidang Bina Pelatihan Dan Penempatan Tenaga Kerja Kabupaten Karawang diantaranya dapat dijabarkan sebagai berikut :

a. Kurangnya kemampuan pegawai dalam menganalisis. 
b. Manajemen organisasi tidak atau kurang memperhatikan prinsip the right man on the right place.

c. Belum adanya SOP yang baku yang mengatur mekanisme supaya pengetahuan (knowledge) dan keterampilan (skill) yang dimiliki orang lama bisa ditransfer kepada karyawan baru.

d. Keterbatasan personil (human resources departement).

e. Bentuk training yang belum tepat.

f. Motivasi karyawan dalam hal belajar untuk berkembang belum merata.

g. Kepemimpinan.

h. Distribusi wewenang tidak merata atau tidak dibagi.

i. Konsep pemberdayaan sumber daya manusia dan konsep human capital yang belum dipahami secara utuh.

Upaya peningkatan kinerja kerja di Dinas Tenaga Kerja Dan Transmigrasi Bidang Bina Pelatihan Dan Penempatan Tenaga Kerja Kabupaten Karawang dapat dilakukan dengan peningkatan kapasitas kerja pegawai melalui peran pendidikan dan pelatihan. Melalui program pemberdayaan sumber daya manusia dan potensi human capital yang ada saat ini, secara umum ditemukan bahwa pimpinan organisasi perlu memberikan perhatian terhadap setiap dimensi dalam peningkatan kinerja, yang meliputi :

a. Pemungkinan (enabling)

b. Penguatan (empowering)

c. Perlindungan (protecting)

d. Penyokongan (supporting)

e. Pemeliharaan (fostering)

Kemudian perbaikan terhadap 5 (lima) dimensi tersebut seharusnya berdampak dalam mengoptimalkan potensi kinerja pegawai melalui human capital. Dimensi peningkatan kapasitas kienrja pada human capital berikut indikator yang bisa dilihat sebagai tanda potensi dari setiap dimensi yang dimaksud adalah sebagai berikut:

a) Kemampuan individual-secara individu pegawai terus mengalami peningkatan dalam kemampuannya.

b) Motivasi individual-pegawai secara umum memiliki motivasi individual yang positif.

c) Kepemimpinan-pegawai mengalami perkembangan dalam berbagai aspek mengenai kualifikasi kepemimpinan.

d) Suasana organisasi - suasana yang diciptakan oleh perusahaan memungkinkan peningkatan dan perkembangan pegawai baik dalam hal pengetahuan (knowledge), keterampilan (skill), kemampuan (ability) maupun sikap (attitude) termasuk motivasi pegawai dalam bekerja.

e) Efektifitas kelompok kerja - hubungan dan kerjasama di antara para pegawai membuat kelompok kerja semakin efektif sehingga menaikkan produktivitas pegawai dan organisasi.

Upaya ini dilakukan dengan langkah atau kebijakan pemberdayaan agar dapat berdampak pada upaya mengoptimalkan kinerja melalui potensi human capital organisasi, di dukung dengan dana yang tersedia. Oleh karena itu beberapa langkah perbaikan pemberdayaan pegawai di organisasi untuk 
mengoptimalkan potensi human capital yang sebaiknya bisa direncanakan dan dilakukan.

Dalam langkah selanjutnya, diharapkan bahwa pemberdayaan sumber daya manusia dengan pendekatan bahwa manusia atau pegawai sebagai human capital diharapkan memberikan dampak signifikan terhadap upaya peningkatan nilai kompetensi pegawai.

\section{Simpulan}

Berdasarkan hasil analisis hasil penelitian, diperoleh kesimpulan sebagai berikut :

1. Implementasi pemberdayaan sumber daya manusia belum dilaksanakan secara optimal.

2. Pelaksanaan program kerja masih berdasarkan capaian yang bersifat rutinitas

3. Faktor yang menjadi penghambat pemberdayaan sumber daya manusia adalah faktor kebiasaan manusia dan disiplin,

4. Faktor yang menjadi penghambat peningkatan kualitas sumber daya manusia adalah faktor budaya kerja yang sudah membentuk dari dulu

5. Upaya peningkatan kinerja dengan mengadakan bimbingan teknis pendidikan dan pelatihan kerjadi Dinas Tenaga Kerja dan Transmigrasi Kabupaten Karawang.

\section{Rekomendasi}

Dari kesimpulan hasil kajian di atas, berikut ini beberapa rekomendasi yang disampaikan sebagai berikut :

1. Pemberdayaan SDM merupakan kebijakan pimpinan, oleh karena itu pimpinan perlu memahami 5 (lima) dimensi dari pemberdayaan SDM.

2. Pimpinan oraganisasi khususnya perlu memahami dan melihat secara utuh potensi human capital.

3. Pimpinan secara rutin melakukan pembinaan dan pendekatan kepada pegawai dalam rangka mendisiplinkan pegawai agar dapat mendorong meningkatkan kemampuan pegawai, sehingga sedikit demi sedikit setiap pegawai akan sadar kepada tugas pokok dan fungsinya dengan demikian capaian kinerja diharapkan dapat meningkat dan program kerja yang sudah direncanakan dan sudah ditetapkan dapat dilaksanakan sesuai dengan apa yang di harapkan.

4. Pimpinan perlu memiliki paradigma dan pemahaman bersama mengenai human capital, dan berbagai dimensi dari human capital.

5. Iklim atau suasana kekeluargaan yang selama ini telah dimiliki sudah sangat baik dan cocok dengan budaya orang Indonesia, dapat terus dipertahankan dan dikembangkan untuk menjadi budaya organisasi sejauh mendukung efektifitas pencapaian tujuan perusahaan dan menjadi motivasi positif bagi pegawai sehingga mereka tetap produktif. .

\section{Daftar Pustaka}

Anwar Prabu Mangkunegara, 2005. Manajemen Sumber Daya Manusia Perusahaan, Cetakan Kedelapan. Bandung: PT Remaja Rosdakarya.

Boyatzis, R,E, Ron, S, 2001, Unleashing the Power of Self Directed Learning, Case Western Reserve University, Cleveland, Ohio, USA

Eysenck, H.J, and Kamin, L, 1981, Intelligence : The Batle For The Mind, Pan Book, London dan Sydney 
Goleman, D, 2000, Kecerdasan Emosi : Mengapa Emotional Intelligence Lebih Tinggi Daripada IQ, Alih Bahasa : T. Hermay, PT. Gramedia PustakaUtama, Jakarta

Goleman, D, 2001, Emotional Intelligence Untuk Mencapai Puncak Prestasi, Alih Bahasa : Alex Tri K.W, PT. Gramedia Pustaka Utama, Jakarta

Moustafa, K,S, and, Miller, T, R, 2003, Too Intelligent For The Job ? The Validity of Upper-Limit Cognitive Ability Test Scores In Selection, Sam AdvancedManagement Journal, Vol.68

Stein, S.J, and Book, H.E, 2002, The EQ Edge : Emotional Intelligence and Your Success, Jossey-Bass, Canada

2010. Evaluasi PelayananPegawai SDM, Cetakan Kelima. Jakarta: Refika Aditama.

Hani, Handoko, 2005. Manajemen Personalia dan Sumber Daya Manusia. UGM, Yogyakarta: BPFE.

L. Mathis, 2002. Manajemen Sumber Daya Manusia "Kebijakan PelayananPegawai". Jakarta : Salemba Empat.

Mangkunegara, A.A.Anwar Prabu , 2000 , Manajemen Sumber Daya Manusia Perusahaan, PT. Remaja Rosda Karya, Bandung.

Nitisemito,Alex S,1995,Manajemen Personalia ( Manajemen Sumber DayaManusia ),Ghalia Indonesia, Jakarta.

Mathis dan Jackson, 2000. Manajemen sumber daya manusia, Jakarta : Salemba Empat.

Robbins, 1998. Essentials of Organizational Behavior (Terjemahan), Edisi Kelima, Penerbit Erlangga, Jakarta.

---------, Stephen P. 2006. Perilaku Organisasi (Terjemahan: Benjamin Molan). Jakarta : PT INDEKS.

Sedarmayanti, 2004,Good Governance ( Kepemerintahan yang Baik ), PenerbitCV. Mandar Maju, Bandung.

Simamora,Henry,1995, Manajemen Sumber Daya Manusia, STIE YKPN,Jakarta.

Simanjutak,Payaman J.,1985,Produktivitas kerja,Pengertian dan RuangLingkupnya,Lembaga Sarana Informasi Usaha dan Produktivitas,Jakarta.

Steers, Richard M, terjemahan Yamin, Magdalena,Pent, 1985 , EfektivitasOrganisasi, Erlangga, Jakarta.

Sugiyono, 2002. Metode Penelitian Bisnis. Bandung: Alfabeta.

Sukanto dan Indriyo, 2000. Manajemen Personalia . Jakarta : Erlangga

Partanto, Kamus Ilmiah Popular, Arkola, Surabaya, 1994.

Zainal Arifin, Bahan Kuliah Manajemen Pendidikan, 2007.

Sulistiorini, Manajemen Pendidikan Islam, Teras, Yogyakarta, 2009.

Sayyid Mahmud Al-Hawary, Al-Idarah Al-Ushus Waususul Ilmiah, (Kairo: Cetakan Ketiga, Tt).

Jalaluddin, Teologi Pendidikan, PT Raja Grafindo Persada, Jakarta, 2002.

Nur Kholis Madjid, Islam Agama Kemanusiaan, Paramadina, Jakarta, 1995.

Muhaimin, Manajemen Pendidikan(Aplikasinya Dalam Penyusunan RencanaPengembangan Sekolah Dan Madrasah), Kencana, Jakarta, 2010.

Davis dalam Mohyi, Teori dan perilaku organisasi, UMM Press, Malang, 1999 .

Kartono, k, pemimpin dan kepemimpinan, Raja grafindo Persada, Jakarta, 1994.

Sarbin T.R dan Allen V.L. "Role Theory" dalam G. Lindzey dan Aronson,eds., Handbook Of Social Psychology, 2 ${ }^{\text {nd }}$. Ed., Reading Mass: Addison Wesley Vol.1: 1968.

Muhaimin DKK, Manajemen Pendidikan, Kencana, Jakarta ,2010. Hal 37

Garry A Yulk, Leadership In Organizations, state unversity of new York al bany, 1992 yang alih bahasakan oleh Jusuf Udaya, Kepemimpinan Dalam Organisasi, Prenhalindo Jakarta, 1998: hal 36-39. 
John W. Creswell. Research Design: Qualitative, Quatitative, and Mixed Methods Approaches. (California, Sage Publication, 2009, Edisi terjelamahan Tahun 2010,

Moustakas, C. Phenomenological Research Methods. (California, Sage Publication, 1994, dalam Creswell, J.W. 2009)

Nieswiadomy, R.M. Foundation of Noursing Research. (Norwalk, CT :Appleton \& Large, 1993, dalam Creswell, J.W. 2009).

Mike Weed (2005). "Meta Interpretation": A Method for the Interpretive Synthesis of Qualitative Research. Forum: Qualitative Social Research Sozial For Schung. Volume 6, No. 1, Art. 37. Jan 2005 (pp 1-21). www.qualitativeresearch.net/index.../1096. Unduh 02-06-2012.

Suryana (2010). Metode Penelitian : Model Praktis Penelitian Kualitatif danKuantitaif. Bandung. Universitas Pendidikan Indonesia. file.upi.edu/.../FPEB/...SURYANA/FILE_7.pdf. Unduh 01-06-2012

Moleong (2007). Dalam Iyan Afriani (2009) Metode Penelitian Kualitatif. www.scribd.com/doc/77525523/116-metode-penelitian-kualitatif. (1-7). Unduh 02-06-2012

Moleong, Lexy J., 2007, Metodologi Penelitian Kualitatif, Bandung : Penerbit PT Remaja Rosdakarya.

Natasha Mack, Cynthia Woodsong, Kathleen M, Macqueen, Greg Guest, Emily Name. (2005). Qualitative Research Methods: A Data Collector's Field Guide. USAIDUSA. Family Health International, pp 12. (1-136) http://www.fhi.org. Unduh 0206-2012

United Nations World Food Programme. (1995) Choosing Methods And Tools For Data Collection : Monitoring \& Evaluation Guidelines. Rome, Italy. Via Cesare Giulio Viola, 68/70 - 00148, web site: www.wfp.org. Unduh 03-06-2012

Suryana. (2010). Metode Penelitian : Model Praktis Penelitian Kualitatif dan Kuantitaif. Bandung. Universitas Pendidikan Indonesia. file.upi.edu/.../FPEB/...SURYANA/FILE_7.pdf. Unduh 01-06-2012

Sugiyono (2010). Memahami Penelitian Kualitatif. Bandung, Edisi Petama, CV. Alfabeta. Indarta Priyana. 2016. Tesis. Kajian pemberdayaan sumber daya manusia dalam upaya mengoptimalkan potensi human capital perusahaan (Studi Kasus pada PT Sinmu di Bandung).

Renstra Disnakertrans 2011-2015.

Lakip Disnakertrans 2011-2015.

http://mulydelavega.blogspot.com/

http://argun-s1.blogspot.com/

Http://elqorni.wordpress.com/

Ibid, http://argun-s1.blogspot.com. 